Article

\title{
Synthesis and Anticancer Evaluation of New 1,3,4-Oxadiazole Derivatives
}

\author{
Camelia Elena Stecoza ${ }^{1}$, George Mihai Nitulescu ${ }^{1, *} \mathbb{D}$, Constantin Draghici ${ }^{2}$, Miron Teodor Caproiu ${ }^{2}$, \\ Octavian Tudorel Olaru ${ }^{1}$, Marinela Bostan ${ }^{3}$ and Mirela Mihaila ${ }^{3}$
}

1 Department of Pharmaceutical Chemistry, Faculty of Pharmacy, "Carol Davila" University of Medicine and Pharmacy, 6 Traian Vuia Street, 020956 Bucharest, Romania; camelia.stecoza@umfcd.ro (C.E.S.); octavian.olaru@umfcd.ro (O.T.O.)

2 "Costin D. Neniţescu" Centre of Organic Chemistry Romanian Academy, 202 B Splaiul Independenţei, 060023 Bucharest, Romania; cst_drag@yahoo.com (C.D.); mct@ccocdn.ro (M.T.C.)

3 Center of Immunology, "Stefan S. Nicolau" Institute of Virology, 030304 Bucharest, Romania; marinela.bostan@virology.ro (M.B.); mirela.mihaila@virology.ro (M.M.)

* Correspondence: george.nitulescu@umfcd.ro

Citation: Stecoza, C.E.; Nitulescu, G.M.; Draghici, C.; Caproiu, M.T.; Olaru, O.T.; Bostan, M.; Mihaila, M. Synthesis and Anticancer Evaluation of New 1,3,4-Oxadiazole Derivatives. Pharmaceuticals 2021, 14, 438. https:// doi.org/10.3390/ph14050438

Academic Editors: Mary Meegan and Niamh M O’Boyle

Received: 8 April 2021

Accepted: 3 May 2021

Published: 6 May 2021

Publisher's Note: MDPI stays neutral with regard to jurisdictional claims in published maps and institutional affiliations.

Copyright: (c) 2021 by the authors. Licensee MDPI, Basel, Switzerland. This article is an open access article distributed under the terms and conditions of the Creative Commons Attribution (CC BY) license (https:/ / creativecommons.org/licenses/by/ $4.0 /)$.
Abstract: In order to develop novel chemotherapeutic agents with potent anticancer activities, a series of new 2,5-diaryl/heteroaryl-1,3,4-oxadiazoles were designed and synthesized. The structures of the new compounds were established using elemental analyses, IR and NMR spectral data. The compounds were evaluated for their anticancer potential on two standardized human cell lines, HT29 (colon adenocarcinoma) and MDA-MB-231 (breast adenocarcinoma). Cytotoxicity was measured by MTS assay, while cell cycle arrest and apoptosis assays were conducted using a flow cytometer, the results showing that the cell line MDA-MB-231 is more sensitive to the compounds' action. The results of the predictive studies using the PASS application and the structural similarity analysis indicated STAT3 and miR-21 as the most probable pharmacological targets for the new compounds. The promising effect of compound 3e, 2-[2-(phenylsulfanylmethyl)phenyl]-5-(4-pyridyl)-1,3,4-oxadiazole, especially on the MDA-MB-231 cell line motivates future studies to improve the anticancer profile and to reduce the toxicological risks. It is worth noting that $3 \mathbf{e}$ produced a low toxic effect in the $D$. magna $24 \mathrm{~h}$ assay and the predictive studies on rat acute toxicity suggest a low degree of toxic risks.

Keywords: cytotoxic agents; apoptosis induction; HT-29 cells; MDA-MB-231 cells; mechanism prediction; STAT inhibitors; miR-21; hydrazide derivatives; nitrogen scaffolds

\section{Introduction}

Cancer, a severe human health issue, is among the leading causes of death on a global scale, and so far chemotherapy remains a main treatment option adopted worldwide either alone or in conjunction with surgery and/or radiotherapy [1]. Despite the significant advancement in chemotherapy over recent decades, which led to major changes in the treatment of various cancers, the main obstacles to the success of the therapy have remained the development of tumor-cell resistance to various chemotherapeutic agents. Drug resistance, either existing before treatment (intrinsic) or generated after therapy (acquired), is responsible for most the relapses of cancer, one of the major causes of death of the disease [2,3].

In the attempt of finding effective anticancer agents, the strategy of using simple druggable scaffolds proved to be successful in finding many relevant lead compounds [4]. A large number of nitrogen-containing heterocyclic compounds were identified as valuable anticancer solutions [5]. Among these, oxadiazoles are receiving particular interest. Depending on the position of the nitrogen and oxygen atoms, the heterocycle may occur in the form of one of the following four different isomers: 1,2,3-, 1,2,4-, 1,2,5-, and 1,3,4-oxadiazole (Figure 1) [6]. 


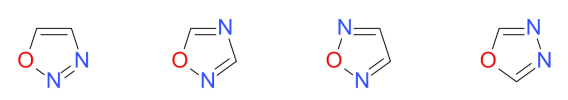

Figure 1. Chemical structures of oxadiazole isomers.

The greatest interest is involved with 1,3,4-oxadiazoles, as in the last years a large number of compounds with cytotoxicity for several tumor lines have been reported. The most active derivatives are more potent than the reference drugs, which proves the high anticancer potential of the 1,3,4-oxadiazole ring [7-11]. The 1,3,4-oxadiazole is an important scaffold in medicinal chemistry, with high versatility, giving rise to elevated structural diversity. In some cases, it acts as a bioisostere for carbonyl-containing compounds such esters, amides, and carbamates or as a flat aromatic linker to provide the appropriate molecular geometry. The stability of the oxadiazole ring in aqueous medium, and its capability to easily interact with bio-targets establishing $\pi-\pi$ interactions or forming strong hydrogen bonds, justify the interest in the development of bioactive molecules containing this scaffold [6].

The versatility and the usefulness of the 1,3,4-oxadiazole scaffold is demonstrated by its use as a core structure in the inhibitors of methionine aminopeptidase (MetAP2) [12], telomerase [13,14], focal adhesion kinase (FAK) [15], thymidylate synthase (TS) [16], glycogen synthase kinase-3 (GSK-3) [17], and thymidine phosphorylase (TP) [18,19]. The antitumor potency of 1,3,4-oxadiazoles derivatives is also related to their ability to inhibit grow factors such as epidermal growth factor receptor (EGFR) [20,21] or vascular endothelial growth factor (VEGF) [22], to inhibit tubulin polymerization [23], histone deacetylases (HDAC) [24,25], or to interact with DNA structures [26]. The structures of the representative anticancer compounds sharing the 1,3,4-oxadiazole scaffold are presented in Figure 2.

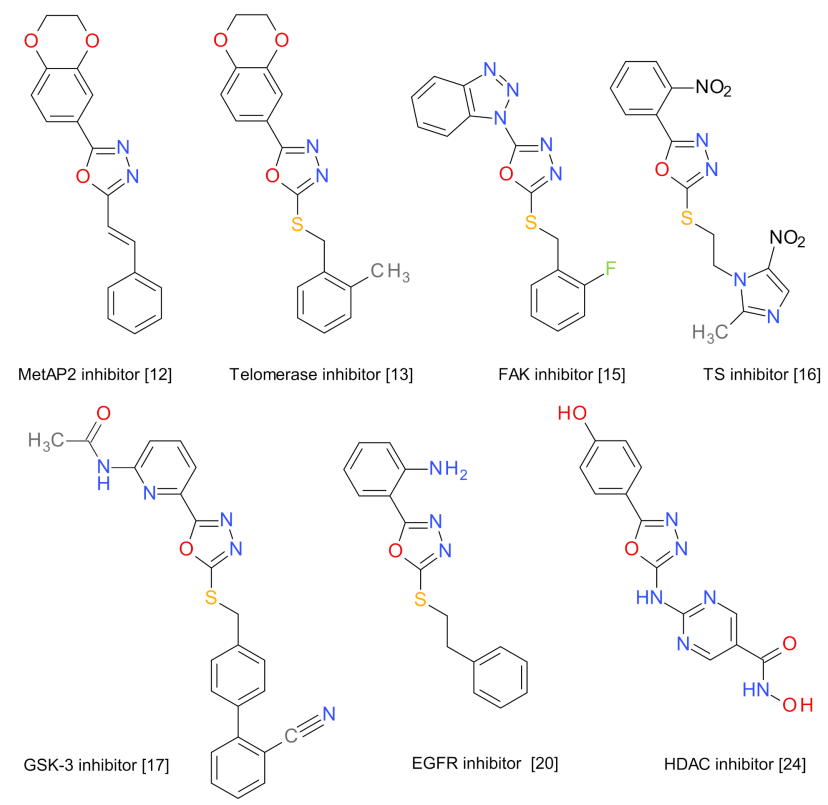

Figure 2. Structure of some representative bioactive compounds containing 1,3,4-oxadiazole moiety as anticancer agents.

In view of the above findings, in order to develop novel chemotherapeutic agents with potent anticancer activities we hereby report the synthesis, characterization and biological evaluation of some new 2,5-diaryl/heteroaryl-1,3,4-oxadiazoles. 


\section{Results}

\subsection{Synthesis Procedures}

The compounds were designed so that the molecular weight is under $500 \mathrm{~g} / \mathrm{mol}$, and the number of hydrogen donors and acceptors comply with the Lipinski rule.

The new 1,3,4-oxadiazole derivatives were prepared by heating under reflux and magnetic stirring of aromatic carboxylic acids $\mathbf{1} \mathbf{a}-\mathbf{d}$ with the hydrazide derivatives $\mathbf{2} \mathbf{a}-\mathbf{b}$ in the presence of phosphorus oxychloride in 59-70\% yields (Scheme 1).

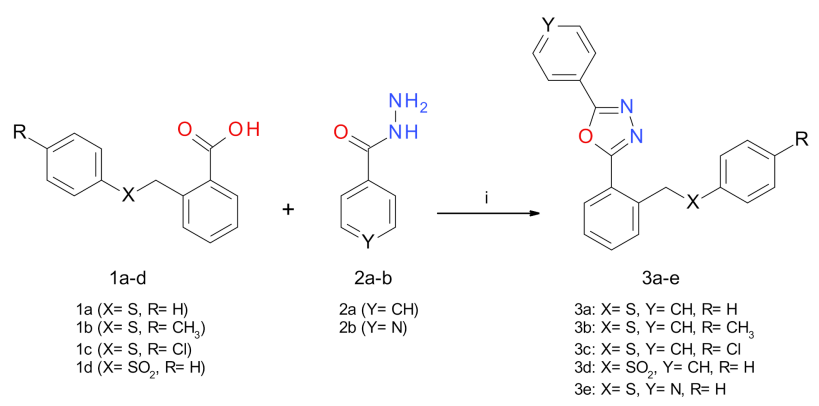

Scheme 1. Synthesis of the target compounds 3a-e. Reagents and conditions: (i) $\mathrm{POCl}_{3}$, reflux, $9 \mathrm{~h}$.

The aromatic carboxylic acids 1a-c were prepared starting from thiophenol or the corresponding $p$-substituted thiophenols and phtalide, according to a previously reported procedure $[27,28]$. A synthetic procedure for the preparation of 2-[(benzenesulfonyl)methyl]benzoic acid (1d) was reported by Patra group [29], and it consists in the reaction of methyl 2(bromomethyl)benzoate with sodium benzenesulfinate in dry dimethylformamide at room temperature, followed by the hydrolysis of the resulting ester with an aqueous solution of sodium hydroxide. The benefit of our synthesis method is the use of an alternative greener approach and the yield advantage.

The new 1,3,4-oxadiazole derivatives 3a-e were prepared by the treatment of aromatic carboxylic acids $\mathbf{1} \mathbf{a}-\mathbf{d}$ with the hydrazide derivatives $\mathbf{2} \mathbf{a}-\mathbf{b}$ in the presence of phosphorus oxychloride. The method was adapted based on previously described procedures [30,31].

Scheme 2 presents the atoms' numbering used for assigning the NMR signals of the new oxadiazole derivatives.

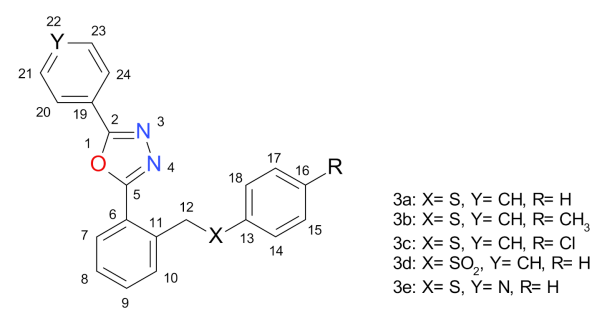

Scheme 2. Structure of the new oxadiazole compounds and the numbering of their atoms.

In the ${ }^{1} \mathrm{H}-\mathrm{NMR}$ spectra of the new compounds, the aromatic hydrogens gave signals in the range of 8.84-6.98 ppm. The methylene group $\mathrm{CH}_{2}(\mathrm{H}-12)$ presented a singlet in the range of 4.64-4.71 ppm for the compounds 3a-c and 3e. In the case of $\mathbf{3 d}$, the S-oxidation induces a deshielding effect that results in an approximately 1 ppm higher chemical shift for the protons of the methylenic group. The methyl group presented a singlet at $2.22 \mathrm{ppm}$.

In the ${ }^{13} \mathrm{C}-\mathrm{NMR}$ spectra, the two signals in the range of $164.50-161.87 \mathrm{ppm}$ are produced by the two carbons in the oxadiazole ring. The carbon atoms of the benzene and the pyridine rings produce signals in the range of $149.80-120.41 \mathrm{ppm}$. The methylene group (C-12) is characterized by a signal at $36.54-38.70 \mathrm{ppm}$ in the compounds $\mathbf{3 a}-\mathbf{c}$ and $\mathbf{3 e}$, and 59.38 ppm in compound $\mathbf{3 d}$.

The IR spectra of the 3a-e compounds differ significantly from the corresponding spectra of the hydrazide derivatives $\mathbf{2} \mathbf{a}-\mathbf{b}$ and those of the acids $\mathbf{1} \mathbf{a}-\mathbf{d}$. 


\subsection{Anticancer Evaluation}

The amplification of the cell division process is responsible for the formation of tumors. Most tumor cells have disorders in the development of the cell cycle, which are associated with an exacerbated proliferative process and this is responsible for the evolution of the tumor process. In addition, the apoptotic process is inhibited in tumor cells [32,33]. In general, cytostatic treatment aims either to induce the apoptotic process of the tumor cells or to cause cell cycle blockage.

To determine the role of the studied compounds on tumor processes, studies were performed on two different types of cancer (colon and breast) using the standardized cell lines HT-29 and MDA-MB-231. The cells treated with the compounds 3a-e and the intermediates $\mathbf{2} \mathbf{a}-\mathbf{b}$ were subjected to flow cytometry techniques in order to examine the apoptotic process and the cell cycle analysis. The apoptotic cells were determined by flow cytometry using Annexin V-FITC and PI (propidium iodide) double labeling. The live cell population, and the cells undergoing early apoptosis (Annexin+/PI-) and late apoptosis (Annexin+/PI+) were quantified [34,35]. The distribution of the cell cycle phases in the tumor cells treated for $24 \mathrm{~h}$ with the studied compounds was analyzed for their DNA content by flow cytometry [36,37].

Cisplatin (CisPt) is frequently used for the treatment of colon adenocarcinoma, while doxorubicin (DOX) is routinely used in the treatment of breast cancers, and was therefore chosen as a reference (CisPt for HT-29 cells, DOX for MDA-MB-231 cells).

\subsubsection{Effects on Cell Viability}

The cell viability after treatment with the compounds and reference drugs was determined using the MTS (3-(4,5-dimethylthiazol-2-yl)-5-(3-carboxymethoxyphenyl)-2-(4sulfophenyl)-2H-tetrazolium). The HT-29 and MDA-MB-231 tumor cells were preliminarily treated with the new compounds in concentrations from $6.25 \mu \mathrm{M}$ up to $200 \mu \mathrm{M}$ for 24 or $48 \mathrm{~h}$ in order to determine the optimal concentration. Two concentrations, $10 \mu \mathrm{M}$ and $50 \mu \mathrm{M}$, were chosen to evaluate the compounds effect on the cells' viability.

The two cell lines responded differently to treatment with the tested compounds. In the HT-29 cell line, the tested compounds reduce viability in a similar way regardless of the concentration used (Figure 3). In contrast, in the MDA-MB231 line, the cell viability is affected more when the compounds are used in a higher concentration $(50 \mu \mathrm{M})$ and the chemical structure has a greater impact, the compound $3 \mathbf{e}$ having the strongest effect (Figure 4). It is noteworthy that all the compounds analyzed have a stronger cytotoxic effect than the effect induced by CisPt or DOX.

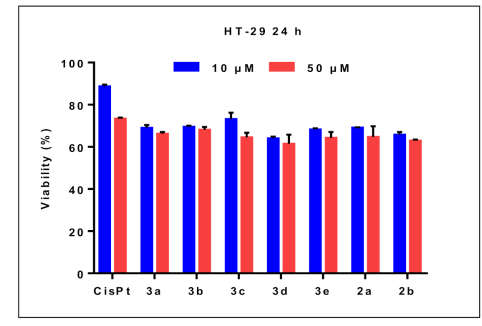

(a)

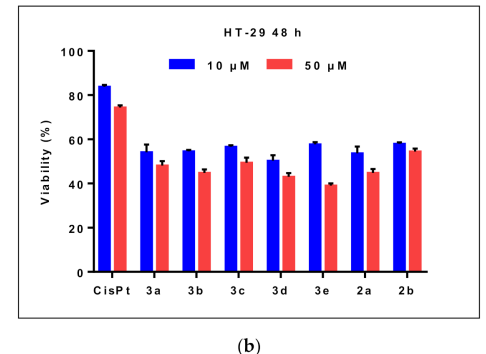

(b)

Figure 3. The tested compounds effects on HT-29 tumor cells' viability. The cells were treated with the compounds compared with cisplatin (CisPt) using two concentrations $10 \mu \mathrm{M}$ or $50 \mu \mathrm{M}$ for $24 \mathrm{~h}$ (a) or $48 \mathrm{~h}$ (b). Untreated cells were considered to have 100\% viability.

The new oxadiazole derivatives $3 a-e$ reduced the HT-29 cells' viability with values in the range of $64.0 \%$ (3d) up to $73.2 \%$ (3c) when exposed for $24 \mathrm{~h}$ at $10 \mu \mathrm{M}$, and with values between $61.5 \%$ (3d) and $68.1 \%(3 \mathrm{~b})$ when the concentration was $50 \mu \mathrm{M}$. The effect of the compounds was higher when the exposure was doubled to $48 \mathrm{~h}$. The cells' viability was between $50.3 \%$ (3d) and $57.7 \%$ (3e) for $10 \mu \mathrm{M}$, and between $39.0 \%$ (3e) and $49.4 \%$ (3c) for the $50 \mu \mathrm{M}$ concentration. 


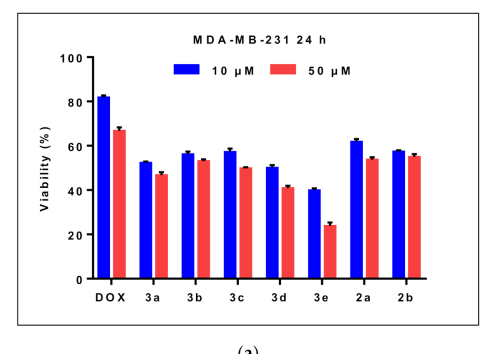

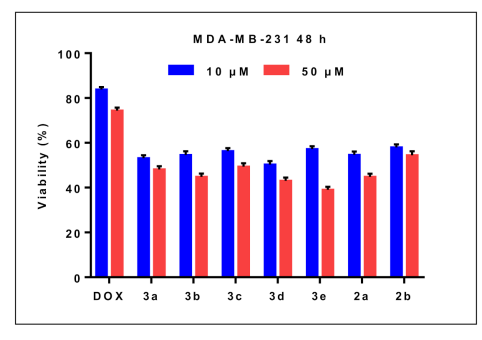

(b)

Figure 4. The tested compounds effects on MDA-MB-231 tumor cells' viability. The cells were treated with the compounds compared with doxorubicin (DOX) using two concentrations $10 \mu \mathrm{M}$ or $50 \mu \mathrm{M}$ for $24 \mathrm{~h}$ (a) or $48 \mathrm{~h} \mathrm{(b)}$. Untreated cells were considered to have 100\% viability.

The compounds 3a-e reduced the MDA-MB-231 cells' viability with values in the range of $39.9 \%$ (3e) up to $57.2 \%$ (3c) when exposed for $24 \mathrm{~h}$ at $10 \mu \mathrm{M}$. The viability values were between $23.8 \%$ (3e) and $53.1 \%$ (3b) when the concentration was $50 \mu \mathrm{M}$. The cells' viability was between $50.8 \%$ (3d) and $56.9 \%$ (3e) after exposure for $48 \mathrm{~h}$ at $10 \mu \mathrm{M}$, and between $38.7 \%$ (3e) and $48.9 \%$ (3c) for the $50 \mu \mathrm{M}$ concentration.

\subsubsection{Effects on Cell Apoptosis}

The HT-29 and MDA-MB-231 cells were treated for $24 \mathrm{~h}$ with the compounds 3a-e and the intermediates $\mathbf{2} \mathbf{a}-\mathbf{b}$, and subjected to a double Annexin/PI staining technique that allowed the detection of the apoptotic process by flow cytometry. CisPt and DOX were used as positive controls (Table 1).

Table 1. Apoptosis of HT-29 cells and MDA-MB-231 cells induced by $24 \mathrm{~h}$ treatment with the tested compounds $3 \mathbf{a}-\mathbf{e}$ and $\mathbf{2 a - b}$.

\begin{tabular}{|c|c|c|c|c|c|c|}
\hline & \multicolumn{3}{|c|}{ HT-29 Cells } & \multicolumn{3}{|c|}{ MDA-MB-231 Cells } \\
\hline & $\begin{array}{c}\text { Early } \\
\text { Apoptosis } \\
(\%)\end{array}$ & $\begin{array}{c}\text { Late } \\
\text { Apoptosis } \\
(\%)\end{array}$ & $\begin{array}{c}\text { Total } \\
\text { Apoptosis } \\
(\%)\end{array}$ & $\begin{array}{c}\text { Early } \\
\text { Apoptosis } \\
(\%)\end{array}$ & $\begin{array}{c}\text { Late } \\
\text { Apoptosis } \\
(\%)\end{array}$ & $\begin{array}{c}\text { Total } \\
\text { Apoptosis } \\
(\%)\end{array}$ \\
\hline Control & 4.8 & 1.1 & 5.9 & 4.2 & 0.5 & 4.7 \\
\hline CisPt ${ }^{1}$ & 16.5 & 4.2 & 20.7 & - & - & - \\
\hline DOX $^{1}$ & - & - & - & 11.4 & 2.3 & 13.7 \\
\hline $3 a$ & 23.5 & 2.2 & 25.7 & 41.7 & 8.0 & 49.7 \\
\hline $3 b$ & 21.7 & 4.8 & 26.5 & 40.5 & 4.7 & 45.2 \\
\hline $3 c$ & 6.4 & 3 & 9.4 & 40.8 & 5.0 & 45.8 \\
\hline $3 d$ & 16.5 & 2.7 & 19.2 & 44.3 & 6.6 & 50.9 \\
\hline $3 e$ & 43.9 & 7.3 & 51.2 & 51.8 & 10.9 & 62.7 \\
\hline $2 a$ & 53.0 & 12.7 & 65.7 & 45.9 & 12.9 & 58.8 \\
\hline $2 b$ & 44.8 & 6.8 & 51.6 & 55.5 & 17.3 & 72.8 \\
\hline
\end{tabular}

${ }_{1}^{1}$ positive controls cisplatin (CisPt) for HT-29 cells and doxorubicin (DOX) for MDA-MB-231 cells.

The treatment of the HT-29 cells for $24 \mathrm{~h}$ with $10 \mu \mathrm{M}$ of the compounds 3a-e increased the total apoptosis in the range of $9.4 \%$ up to $51.2 \%$ compared to the untreated cells (control, $5.9 \%$ ). Considering the compound 3a, the introduction of a 4-chloro substituent is detrimental for the apoptotic effect (compound 3c), while the transformation of the sulfur atom into a sulfone (compound 3d) slightly reduced the effect. The exchange of the benzene ring with a pyridine (compound $\mathbf{3 e}$ ) almost doubled the proportion of apoptotic cells.

The new oxadiazole compounds had greater effects on the MDA-MB-231 cells compared to those observed on the HT-29 cells, with the total apoptosis percent's in the range of $45.2 \%$ up to $62.7 \%$. All the compounds had close to three-fold stronger effects than those of the positive control. The observed structure activity relationships are similar, but the impact of the structural transformation is smaller. The compound 3e determined the greatest effect in the oxadiazoles series, but it was smaller when compared with its precursor hydrazide $\mathbf{2} \mathbf{b}$ (Figure 5). 


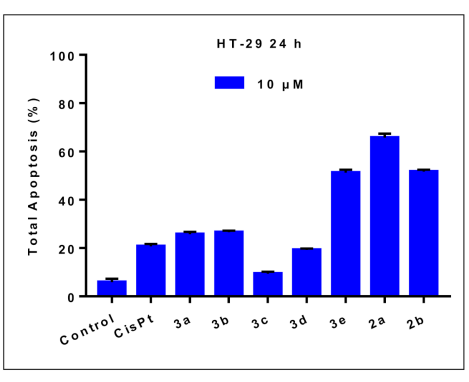

(a)

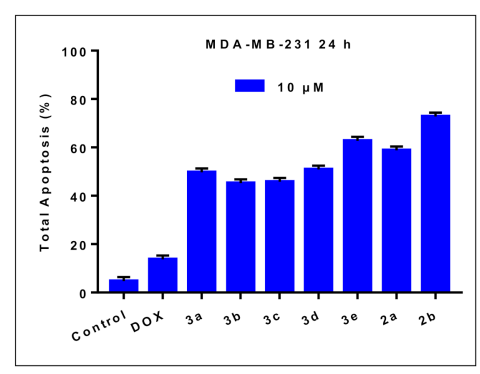

(b)

Figure 5. The tested compounds effects on cells' apoptosis. The cells were treated with the test compounds at $10 \mu \mathrm{M}$ for $24 \mathrm{~h}$. The effects on HT-29 cells can be observed compared to cisplatin (CisPt) (a) and the effects on MDA-MB-231 cells are reported to doxorubicin (DOX) (b).

\subsubsection{Cell Cycle Analysis}

A flow cytometry method was used to analyze the effect induced by the studied compounds on the cell cycle of the HT-29 tumor cells compared to the effect induced by CisPt, and on the cell cycle of the MDA-MB-231 tumor cells using DOX as a positive control (Figure 6).

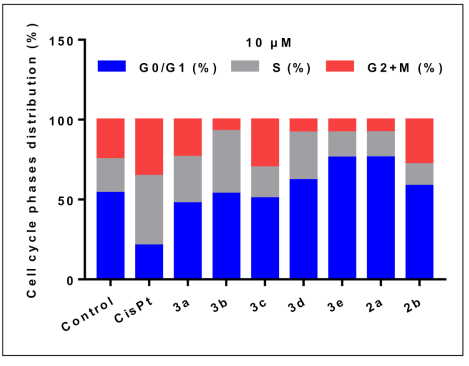

(a)

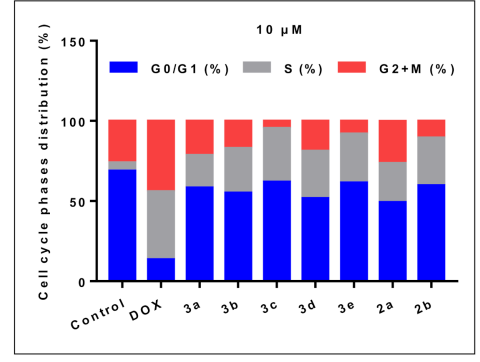

(b)

Figure 6. The tested compounds' effects on cell cycle phases. The cells were treated with the test compounds at $10 \mu \mathrm{M}$ for $24 \mathrm{~h}$. The effects on HT-29 cells can be observed compared to cisplatin (CisPt) (a) and the effects on MDA-MB-231 cells are reported to doxorubicin (DOX) (b).

The treatment of the HT-29 cells for $24 \mathrm{~h}$ with CisPt $10 \mu \mathrm{M}$ induced a decrease in the G0/G1 phase from $54 \%$ to $21 \%$, accompanied by an increase in the S phase of the cell cycle to $43.5 \%$ compared to the untreated cells $(21.2 \%)$. The oxadiazoles $3 \mathbf{a}-\mathbf{d}$ did not significantly alter the proportion of G0/G1 phase cells compared to untreated cells, while increasing the number of $S$ phase cells. The compound 3 e caused a different effect, augmenting the G0/G1 phase accompanied by a decrease in the S phase.

The flow cytometry analysis on the cell cycle of the MDA-MB-231 tumor cells showed a high percentage of G0/G1 phase (68.9\%). The treatment with DOX $10 \mu \mathrm{M}$ induced a synchronization of the $S$ and $\mathrm{G} 2+\mathrm{M}$ phases, registering an increase in the $S$ phase $(42.4 \%)$ versus the untreated cells (5.1\%), accompanied by an increase in the $\mathrm{G} 2+\mathrm{M}$ phases $(43.9 \%)$ versus $26 \%$ in the untreated cells. The analyzed compounds determined the arrest of the cells in the G0/G1 phase, accompanied by a decrease in the $S$ and G2+M phases. The compound $3 \mathbf{e}$ had the greatest impact of the oxadiazoles series, increasing the number of cells in G0/G1 and significantly reducing those in the $S$ phase.

\subsection{Daphnia Magna Toxicity Assay}

The Daphnia magna (D. magna) bioassay results are summarized in Table 2. After $24 \mathrm{~h}$ of exposure, the compounds $3 \mathbf{b}-\mathbf{e}$ induced at all the tested concentrations a lethality rate (L\%) lower than $50 \%$, whereas $3 a$ induced an $\mathrm{L} \%$ of $55 \%$ at the highest concentration. Due to the obtained results, the median lethal concentration (LC50) was calculated only for the compounds $\mathbf{3 a}, \mathbf{2} \mathbf{a}$ and $\mathbf{2 b}$. Although the LC50 for $\mathbf{2} \mathbf{b}$ was slightly lower than $\mathbf{2 a}$, the $95 \% \mathrm{CI}$ of both compounds suggest a similar biological response. 
Table 2. Daphnia magna bioassay: $24 \mathrm{~h}$ and $48 \mathrm{~h}$ values, $95 \%$ confidence intervals for newly synthetized compounds and their starting materials.

\begin{tabular}{|c|c|c|c|c|}
\hline \multirow{2}{*}{ Compound } & \multicolumn{2}{|r|}{$24 \mathrm{~h}$} & \multicolumn{2}{|r|}{$48 \mathrm{~h}$} \\
\hline & LC50 $(\mu \mathrm{M})$ & $95 \%$ CI of LC50 $(\mu \mathrm{M})$ & LC50 $(\mu \mathrm{M})$ & $95 \%$ CI of LC50 $(\mu \mathrm{M})$ \\
\hline $3 a$ & 115.8 & 43.6 to 307.4 & $\mathrm{ND}^{*}$ & $\mathrm{ND}^{*}$ \\
\hline $3 b$ & $\mathrm{ND}^{*}$ & $\mathrm{ND}^{*}$ & $\mathrm{ND}^{*}$ & $\mathrm{ND}^{*}$ \\
\hline $3 c$ & $\mathrm{ND}^{*}$ & $\mathrm{ND}^{*}$ & 11.5 & $\mathrm{ND}^{*}$ \\
\hline $3 d$ & $\mathrm{ND}^{*}$ & $\mathrm{ND}^{*}$ & 2.34 & $\mathrm{ND}^{*}$ \\
\hline $3 e$ & $\mathrm{ND}^{*}$ & $\mathrm{ND}^{*}$ & 3.5 & $2.0-7.3$ \\
\hline $2 a$ & 332.5 & $201.1-549.8$ & 35.9 & $23.0-56.1$ \\
\hline $2 b$ & 296.0 & $205.3-426.7$ & 21.8 & $11.5-41.1$ \\
\hline
\end{tabular}

ND*-not determined due the results obtained.

After $48 \mathrm{~h}$ of exposure, all the newly tested compounds exhibited a significantly higher toxicity on D. magna. The LC50 value was not calculated for $3 \mathbf{a}$ and $\mathbf{3 b}$ because they induced an $\mathrm{L} \%$ between 55 and $85 \%$ at all the concentrations. In the case of the compounds $3 \mathbf{c}-\mathbf{e}$, the calculated LC50 values are between 2.34 and $11.5 \mu \mathrm{M}$.

\subsection{Prediction of the Molecular Mechanism of Action and Toxicity}

\subsubsection{PASS Prediction}

The prediction of an activity spectra for substances (PASS) is an algorithm that predicts a large panel of biological activities of a given molecule using its structure as input data, and yields a probability to be active $(\mathrm{Pa})$ and a probability to be inactive $(\mathrm{Pi})$ for each target [38] Each compound's target profile was manually analyzed, the relevant oncotargets were selected, and the corresponding Pa values are presented in Table 3.

Table 3. The probability of compounds 3a-e to be active (Pa) as predicted by PASS analysis.

\begin{tabular}{cccccc}
\hline Target & 3a & 3b & 3c & 3d & 3e \\
\hline Transcription factor inhibitor & 0.58 & 0.62 & 0.55 & 0.32 & 0.58 \\
Transcription factor STAT inhibitor & 0.61 & 0.64 & 0.61 & 0.42 & 0.65 \\
Transcription factor STAT3 inhibitor & 0.55 & 0.58 & 0.56 & 0.26 & 0.54 \\
JAK2 expression inhibitor & 0.40 & 0.33 & 0.40 & 0.33 & 0.22 \\
Focal adhesion kinase inhibitor & 0.23 & 0.22 & 0.22 & 0.24 & 0.27 \\
Focal adhesion kinase 2 inhibitor & 0.35 & 0.34 & 0.34 & 0.36 & 0.38 \\
MAP3K5 inhibitor & 0.28 & 0.26 & - & - & 0.29 \\
Vascular endothelial growth factor 1 & 0.27 & 0.22 & 0.22 & 0.30 & 0.30 \\
antagonist & & & & & \\
\hline
\end{tabular}

The Pa values are an indication of the possibility that a compound interacts with a certain biological target, but not for the potency of the compound. The Pa values indicate the inhibition of STAT transcription factors, especially STAT3, as the most probable mechanism for the anti-proliferative effects of the compounds 3a-e. The results for the compounds $\mathbf{3 d}$ and $\mathbf{3 a}$ indicate that the (phenylsulfonyl)methyl substitution reduces the probability to inhibit STAT3 compared to the phenylthiomethyl substitution.

\subsubsection{Structural Similarity Analysis}

The similarity search on ChEMBL database returned 27 analog compounds, all sharing a 1,3,4-oxadiazole central scaffold. The highest degree of structural similarity $(65.00 \%)$ was observed for the compound CHEMBL485773. The results highlight the originality of the new synthesized compounds. Depending on their structure, the ChEMBL compounds are registered to interact with various human targets. The most frequent targets are represented by microRNA 21 (77.78\%), Ras-related protein Rab-9A (62.96\%), Niemann-Pick C1 protein $(59.26 \%)$, survival motor neuron protein $(48.15 \%)$, and 15-hydroxyprostaglandin dehydrogenase $(40.74 \%)$. In Figure 7 the corresponding pIC50 or pEC50 values are represented for the most relevant oncological target registered for the similar compounds. 


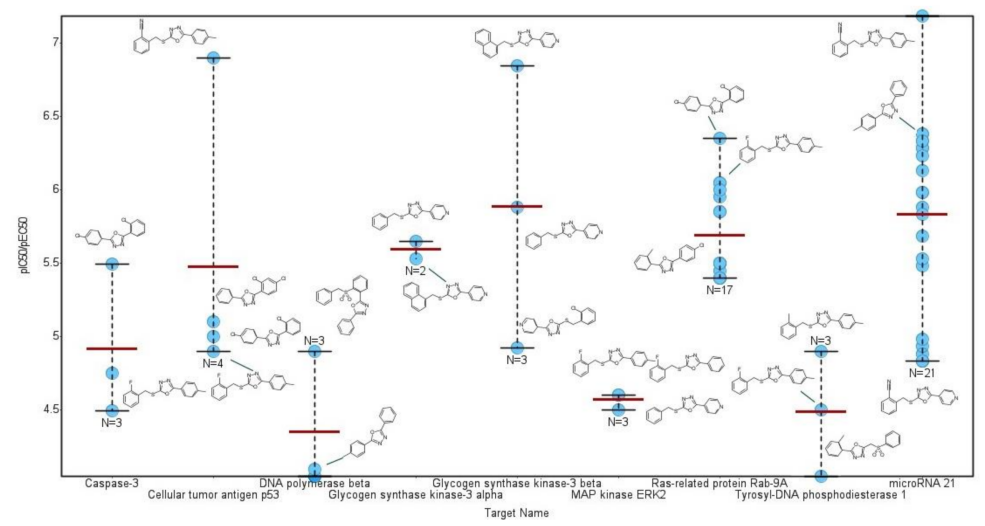

Figure 7. Structures and negative log of potency measurement for compounds structurally similar with the target structures 3a-e. The compounds were extracted from the ChEMBL database and share a similarity over $50 \%$ with the new synthesized compounds. The red lines represent the average value for each target.

The target profile of the chemically similar compounds indicates the interaction with microRNA 21 (miR-21), Ras-related protein Rab-9A, glycogen synthase kinase-3 beta, and cellular tumor antigen p53, as the most probable interaction targets for the new synthesized compounds 3a-e.

\subsubsection{Predicted Acute Rat Toxicity}

For all the compounds, the predicted results fall in the applicability domain of the application. The predicted median lethal dose (LD50) of the new compounds after oral and intravenous (IV) administration on rats are presented in Table 4, and they indicate a relatively low degree of toxicity. All the new oxadiazole derivatives are predicted to be less toxic than their corresponding hydrazides synthesis precursors.

Table 4. The predicted toxicity of the compounds $\mathbf{3 a}-\mathbf{e}$ and $\mathbf{2} \mathbf{a}-\mathbf{b}$ expressed as median lethal doses (LD50) on rats using the GUSAR application.

\begin{tabular}{cccccccc}
\hline Rat Acute Toxicity & $\mathbf{3 a}$ & $\mathbf{3 b}$ & $\mathbf{3 c}$ & $\mathbf{3 d}$ & $\mathbf{3 e}$ & $\mathbf{2 a}$ & $\mathbf{2 b}$ \\
\hline Oral LD50 $(\mathrm{mg} / \mathrm{kg})$ & 1970 & 1977 & 1317 & 1417 & 1924 & 967 & 900 \\
Oral LD50 Class & 4 & 4 & 4 & 4 & 4 & 4 & 4 \\
IV LD50 (mg/kg) & 321.1 & 289.6 & 253.3 & 383.0 & 298.8 & 135.7 & 256.1 \\
IV LD50 Class & 5 & 4 & 4 & 5 & 4 & 4 & 4 \\
\hline
\end{tabular}

\section{Discussion}

A series of new 2,5-diaryl/heteroaryl-1,3,4-oxadiazoles were synthesized and evaluated for their anticancer potential on two standardized cell lines, HT-29 and MDA-MB-231. At $10 \mu \mathrm{M}$, all the compounds reduced the cell viability after $24 \mathrm{~h}$ of exposure, inducing apoptosis and perturbation of the cell cycle. The cell line MDA-MB-231 proved to be more sensitive to the compounds' action than HT-29.

The predictive studies using the PASS application indicated the inhibition of the STAT3 transcription factor as the most probable anticancer mechanism. Recent evidence shows that the 1,3,4-oxadiazole scaffold is frequently used in the structure of STAT3 inhibitors active against various cancer cells [39-41]. STAT3 is closely related to the occurrence of cancers and is an attractive therapeutic target for oncology and drug development. It acts in the regulation of many cellular events involving cell proliferation, differentiation, apoptosis and angiogenesis [42]. N-[2-(1,3,4-oxadiazolyl)]-4-quinolinecarboxamide, also known as STX-0119, is structurally similar to the 3a-e compounds and functions as a STAT3 dimerization inhibitor [43]. HJC0123 was developed based on the structure of STX-0119, but it does not contain the oxadiazole scaffold. When administered in the MDA-MB-231 
cells, the compound blocked the phosphorylation of STAT3, reduced the cells' viability, promoted apoptosis, and increased the proportion of S-phase cells while reducing the number of cells in G0/G1 [44]. The effects of HJC0123 in the MDA-MB-231 cells are similar with those observed for compound 3e. In contrast to MDA-MB-231 tumor cell lines, STAT3 plays no major role in the colon carcinoma cell line HT-29 [45] and it could explain the lower effects of the new compounds on this cell line.

The structural similarity analysis indicated miR-21 as a highly probable target for the new compounds. MiR-21 is considered an oncomir because it is one of the most frequently up-regulated miRNA in a wide type of cancers. MiR-21 is overexpressed in the MDA-MB231 cell line close to four-fold compared with the non-tumorigenic MCF-10A cell line. The knockdown of miR-21 suppressed the cell growth and proliferation of the MDA-MB-231 cells [46]. The levels of miR-21 are also significantly higher in the HT-29 cells and promote cell proliferation and migration [47].

The results of the predictive studies using the PASS application and the structural similarity analysis indicated STAT3 and miR-21 as the most probable pharmacological targets for the new compounds 3a-e, but also that these compounds may have multitarget activities. This is suggested also by the significant toxic effects registered in the D. magna $48 \mathrm{~h}$ assay.

The chemical diversity of the $3 a-\mathbf{a}$ structures, and the limited number of tested compounds, limits the development of structure activity relationships. The compound $3 \mathbf{e}$ presented the best anticancer profile of the series, probably due to the presence of the pyridine ring next to the oxadiazole structure. The promising effect of the compound $3 \mathbf{e}$, especially on the MDA-MB-231 cell line, a triple-negative breast cancer line, motivates future studies to improve the anticancer profile and to reduce the toxicological risks. It is worth noting that $3 \mathbf{e}$ produced a low toxic effect in the D. magna $24 \mathrm{~h}$ assay and the predictive studies on rat acute toxicity suggest a low degree of toxic risks.

\section{Materials and Methods}

\subsection{Analytical Procedures}

The melting points (m.p.) were measured in open capillary tubes on an Electrothermal 9100 apparatus and are uncorrected. The ${ }^{1} \mathrm{H}-\mathrm{NMR}$ and ${ }^{13} \mathrm{C}-\mathrm{NMR}$ spectra were recorded on a Gemini 300 BB instrument (Varian, Palo Alto, CA, USA) at room temperature, operating at $300 \mathrm{MHz}$ for ${ }^{1} \mathrm{H}$ and $75.075 \mathrm{MHz}$ for ${ }^{13} \mathrm{C}$. The chemical shifts were recorded as $\delta$ values in ppm units downfield to tetrametylsilane (TMS) used as internal standard, and $\mathrm{CDCl}_{3}$ and DMSO-d6 as solvents. The coupling constants values $(J)$ are reported in hertz $(\mathrm{Hz})$ and the splitting patterns are abbreviated as follows: $s$, singlet; $d$, doublet; $t$, triplet; $q$, quartet; and $\mathrm{b}$, broad. The carbons not attached to any protons are presented as $\mathrm{Cq}$, while those attached to a hydrogen atom are designated as $\mathrm{CH}$.

The IR spectra were recorded on a FT/IR-4200 spectrometer (JASCO, Tokyo, Japan) with an ATR PRO450-S accessory at a resolution of $4 \mathrm{~cm}^{-1}$. The elemental analyses were performed on a Perkin-Elmer 2400 Series II CHNS/O Elemental Analyzer (Shelton, CT, USA).

\subsection{Synthesis Procedures}

All the chemicals and reagents were purchased from commercial suppliers and used without purification, unless otherwise noted.

\subsubsection{Synthesis of 2-[(benzenesulfonyl)methyl]benzoic acid (1d)}

To a solution of 2-(phenylthiomethyl)benzoic acid (1a) $(0.02 \mathrm{~mol})$ in glacial acetic acid (100 mL), $20 \mathrm{~mL} \mathrm{30 \%} \mathrm{aqueous} \mathrm{hydrogen} \mathrm{peroxide} \mathrm{was} \mathrm{added} \mathrm{dropwise.} \mathrm{The} \mathrm{mixture} \mathrm{was}$ heated for $2 \mathrm{~h}$ and then left overnight at room temperature. The reaction mixture was diluted with water and extracted with chloroform. The separated organic phase was dried over sodium sulfate and then concentrated under reduced pressure. The crude product was recrystallized from ethanol. 
White solid. Yield 93\%, m.p. $154-155{ }^{\circ} \mathrm{C}$. IR $\left(\mathrm{cm}^{-1}\right) .{ }^{1} \mathrm{H}-\mathrm{NMR}\left(300 \mathrm{MHz}, \mathrm{CDCl}_{3}\right.$, $\delta \mathrm{ppm}, J \mathrm{~Hz}): 8.86$ (bs, $1 \mathrm{H}) ; 8.05(\mathrm{dd}, 1 \mathrm{H}, 1.4,7.5) ; 7.64(\mathrm{dd}, 2 \mathrm{H}, 1.4,7.5) ; 7.59(\mathrm{tt}, 1 \mathrm{H}, 1.4$, 7.2); $7.55(\mathrm{td}, 1 \mathrm{H}, 1.4,7.5) ; 7.49(\mathrm{~m}, 1 \mathrm{H}) ; 7.46(\mathrm{~m}, 2 \mathrm{H}) ; 7.35(\mathrm{dd}, 1 \mathrm{H}, 1.4,7.5) ; 5.10(\mathrm{~s}, 2 \mathrm{H})$. ${ }^{13} \mathrm{C}-\mathrm{NMR}\left(75.075 \mathrm{MHz}, \mathrm{CDCl}_{3}\right.$, $\left.\delta \mathrm{ppm}\right): 171.88$ (C-7); 137.90 (C-9); 129.97 (C-2); 129.45 (C-1); 129.04 (C-3); 128.98 (C-11, C-13); 128.62(C-10, C-14); 133.88(C-4 or C-5); 133.74 (C-12); 133.02 (C-5 or C-4); 131.86 (C-6); 59.46 (C-8). Elemental analysis calculated for $\mathrm{C}_{14} \mathrm{H}_{12} \mathrm{O}_{4} \mathrm{~S}$ (276.31 g/mol): C 60.86\%, H 4.38\%, S 11.60\% and found: C 60.94\%, H 4.28\%, S 11.69\%.

4.2.2. General Procedure for the Synthesis of the 1,3,4-oxadiazoles Derivatives (3a-e)

An equimolar mixture of benzoyl hydrazine $(2 \mathrm{a}, 0.01 \mathrm{~mol})$ or isonicotinic hydrazide $(\mathbf{2 b}, 0.01 \mathrm{~mol})$ and the appropriate aromatic acid $(\mathbf{1 a}-\mathbf{d})(0.01 \mathrm{~mol})$ in phosphorus oxychloride $(45 \mathrm{~mL})$ was refluxed for $9 \mathrm{~h}$. The reaction mixture was slowly poured onto crushed ice and kept overnight. The solid thus separated out was filtered and washed with water, dried under vacuum and recrystallized from an appropriate solvent.

\subsubsection{2-Phenyl-5-[2-(phenylsulfanylmethyl)phenyl]-1,3,4-oxadiazole (3a)}

White solid. Yield $69 \%$, m.p. $111-112{ }^{\circ} \mathrm{C} .{ }^{1} \mathrm{H}-\mathrm{NMR}\left(300 \mathrm{MHz}, \mathrm{CDCl}_{3}, \delta \mathrm{ppm}, J \mathrm{~Hz}\right)$ : 8.03 (dd, 7.7, 1.6, 2H, H-20, H-24); 7.95 (ddd, 1H, H-7); 7.42-7.49 m (3H, H-21, H-22, H-23); 7.27-7.35 m (3H; H-8, H-9, H-10); 7.22 td (2H, H-14, H-18); 7.07-7.15 m (3H, H-15, H-16, H-17): 4.64 (s, 2H, H-12). ${ }^{13} \mathrm{C}-\mathrm{NMR}\left(75.075 \mathrm{MHz}, \mathrm{CDCl}_{3}, \delta \mathrm{ppm}\right): 164.39$ (C-2 or C-5); 164.26 (C-2 or C-5); $138.07(\mathrm{Cq}) ; 135.60(\mathrm{Cq}) ; 131.90(\mathrm{CH}) ; 131.61(2 \mathrm{CH}) ; 131.44(\mathrm{CH}) ; 131.39$ $(\mathrm{CH}) ; 129.51(\mathrm{CH}) ; 129.23(2 \mathrm{CH}) ; 128.90(2 \mathrm{CH}) ; 127.75(\mathrm{CH}) ; 127.13(2 \mathrm{CH}) ; 127.02(\mathrm{CH})$; $123.97(\mathrm{CH}) ; 122.84(\mathrm{CH}) ; 38.30(\mathrm{C}-12)$. Elemental analysis calculated for $\mathrm{C}_{21} \mathrm{H}_{16} \mathrm{~N}_{2} \mathrm{OS}$ (344.44 g/mol): C 73.23\%, H 4.68\%, N 8.13\%, S 9.31\% and found: C 73.31\%, H 4.60\%, N $8.20 \%$, S $9.24 \%$.

\subsubsection{2-Phenyl-5-[2-(p-tolylsulfanylmethyl)phenyl]-1,3,4-oxadiazole (3b)}

White solid. Yield $68 \%$, m.p. $116-117^{\circ} \mathrm{C} .{ }^{1} \mathrm{H}-\mathrm{NMR}\left(300 \mathrm{MHz}, \mathrm{CDCl}_{3}, \delta \mathrm{ppm}, J \mathrm{~Hz}\right)$ : 8.11 (dd, 7.4, 1.5, 2H, H-20, H-24); 8.01 (dd, 7.0, 2.2, 1H, H-7); 7.48-7.58 (m, 3H, H-8, H-9, $\mathrm{H}-10) ; 7.40$ (t, 6.5, 2H, H-21, H-23); 7.31 (t, 6.5, 1H, H-22); 7.17 (d, 8.1, 2H, H-15, H-17); 6.98 (d, 8.1, 2H, H-14, H-18); 4.66 (s, 2H, H-12); 2.22 (s, 3H, $\left.\mathrm{CH}_{3}\right) .{ }^{13} \mathrm{C}-\mathrm{NMR}(75.075 \mathrm{MHz}$, $\mathrm{CDCl}_{3}, \delta \mathrm{ppm}$ ): 164.21 (C-2 or C-5); 164.16 (C-2 or C-5); 138.32 (Cq); 137.20 (Cq); 137.19 (Cq); $132.38(\mathrm{CH}) ; 132.28(\mathrm{CH}) ; 131.73(\mathrm{CH}) ; 131.34(\mathrm{CH}) ; 131.21(\mathrm{CH}) ; 129.51(2 \mathrm{CH}) ; 129.32$ $(\mathrm{CH}) ; 129.07(2 \mathrm{CH}) ; 127.49(\mathrm{CH}) ; 126.96(2 \mathrm{CH}) ; 123.83(\mathrm{Cq}) ; 122.64(\mathrm{Cq}) ; 38.70(\mathrm{C}-12) ; 21.01$ $\left(\mathrm{CH}_{3}\right)$. Elemental analysis calculated for $\mathrm{C}_{22} \mathrm{H}_{18} \mathrm{~N}_{2} \mathrm{OS}(358.47 \mathrm{~g} / \mathrm{mol}): \mathrm{C} 73.72 \%, \mathrm{H} 5.06 \%$, N 7.81\%, S 8.94\% and found: C 73.81\%, H 4.98\%, N 7.72\%, S 9.01\%.

\subsubsection{2-[2-[(4-Chlorophenyl)sulfanylmethyl]phenyl]-5-phenyl-1,3,4-oxadiazole (3c)}

White solid. Yield $60 \%$, m.p. $126-128{ }^{\circ} \mathrm{C} .{ }^{1} \mathrm{H}-\mathrm{NMR}\left(\mathrm{CDCl}_{3}, \delta \mathrm{ppm} J \mathrm{~Hz}\right): 8.06$ (dd, 1.6, 7.5, 2H, H-20, H-24); 7.97 ddd (1H, H-7); 7.47-7.50 m (3H, H-21, H-22, H-23); 7.38-7.35 m (2H; H-9, H-10); 7.26 (dd, 1H, H-8); 7.16 (d, 8.8, 2H, H-14, H-18); 7.10 (d, 8.8, 2H, H-15, $\mathrm{H}-17) ; 4.65$ (s, 2H, H-12); ${ }^{13} \mathrm{C}-\mathrm{NMR}\left(\mathrm{CDCl}_{3}, \delta\right.$ ppm): 164.42 (C-2(5)); 164.16 (C-5(2)); 137.85 (C-13); $134.03(\mathrm{Cq}) ; 133.73(\mathrm{Cq}) ; 133.21(2 \mathrm{CH}) ; 131.98(\mathrm{CH}) ; 131.43(2 \mathrm{CH}) ; 129.53(\mathrm{CH})$; $129.26(2 \mathrm{CH}) ; 129.04(2 \mathrm{CH}) ; 127.91(\mathrm{CH}) ; 127.16(2 \mathrm{CH}) ; 123.92(\mathrm{Cq}) ; 122.87(\mathrm{Cq}) ; 38.56(\mathrm{C}-12)$. Elemental analysis calculated for $\mathrm{C}_{21} \mathrm{H}_{15} \mathrm{ClN}_{2} \mathrm{OS}(378.88 \mathrm{~g} / \mathrm{mol}): \mathrm{C} 66.57 \%, \mathrm{H} 3.99 \%, \mathrm{~N}$ $7.39 \%$, S 8.46\% and found: C $66.68 \%$, H 3.82\%, N 7.48\%, S 8.32\%.

\subsubsection{2-[2-(Benzenesulfonylmethyl)phenyl]-5-phenyl-1,3,4-oxadiazole (3d)}

White solid. Yield 59\%, m.p. $195-196{ }^{\circ} \mathrm{C} .{ }^{1} \mathrm{H}-\mathrm{NMR}\left(300 \mathrm{MHz}, \mathrm{CDCl}_{3}, \delta \mathrm{ppm}, J \mathrm{~Hz}\right)$ : 7.97 (dd, 8.0, 2.4, 2H, H-14, H-18); 7.77 (dd, 7.1, 1.8, 1H, H-7); 7.00-7.60 (m, 11H, H-arom); 5.26 (s, 2H, H-12). ${ }^{13} \mathrm{C}-\mathrm{NMR}\left(75.075 \mathrm{MHz}, \mathrm{CDCl}_{3}, \delta \mathrm{ppm}\right.$ ): 164.05 (C-2 or C-5); 163.46 (C-2 or C-5); 138.07 (Cq); $134.03(\mathrm{CH}) ; 133.48(\mathrm{CH}) ; 132.09(\mathrm{CH}) ; 131.60(\mathrm{CH}) ; 129.46(\mathrm{CH}) ; 129.27$ $(2 \mathrm{CH}) ; 129.09(\mathrm{CH}) ; 128.87(\mathrm{CH}) ; 128.72(2 \mathrm{CH}) ; 128.69(\mathrm{CH}) ; 127.99(\mathrm{Cq}) ; 127.02(2 \mathrm{CH})$; $124.37(\mathrm{Cq}) ; 123.53(\mathrm{Cq}) ; 59.38(\mathrm{C}-12)$. Elemental analysis calculated for $\mathrm{C}_{21} \mathrm{H}_{16} \mathrm{~N}_{2} \mathrm{O}_{3} \mathrm{~S}$ 
(376.44 g/mol): C $67.01 \%, \mathrm{H} 4.28 \%$, N 7.44\%, S 8.52\% and found: C $67.09 \%, \mathrm{H} 4.19 \%$, N $7.38 \%$, S 8.60\%.

\subsubsection{2-[2-(Phenylsulfanylmethyl)phenyl]-5-(4-pyridyl)-1,3,4-oxadiazole (3e)}

White solid. Yield 70\%, m.p. $130-132{ }^{\circ} \mathrm{C} .{ }^{1} \mathrm{H}-\mathrm{NMR}\left(300 \mathrm{MHz}\right.$, DMSO-d6 $+\mathrm{CDCl}_{3}$ 3:1, $\delta$ ppm, J Hz): 8.84 (d, 5.8, 2H, H-21, H-23); 8.07 (td, 4.0, 2.0, 1H, H-7); 8.03 (d, 5.8, 2H, H-20, H-24); 7.39-7.49 (m, 3H, H-8, H-9, H-10); 7.13-7.26 (m, 5H, H-14, H-15, H-16, H-17, $\mathrm{H}-18) ; 4.71$ (s, 2H, H-12). ${ }^{13} \mathrm{C}-\mathrm{NMR}$ (75.075 MHz, DMSO-d6 + $\mathrm{CDCl}_{3}$ 3:1, $\left.\delta \mathrm{ppm}\right): 164.50$ (C-2 or C-5); 161.87 (C-2 or C-5); 149.90 (C-21, C-23); 137.56 (Cq); 135.07 (Cq); 131.63 (CH); $131.14(\mathrm{CH}) ; 131.03(\mathrm{CH}) ; 129.97(2 \mathrm{CH}) ; 129.50(\mathrm{CH}) ; 128.64(2 \mathrm{CH}) ; 127.73(\mathrm{CH}) ; 126.37(\mathrm{CH})$; $121.70(\mathrm{CH}) ; 120.41(2 \mathrm{CH}) ; 36.54(\mathrm{C}-12)$. Elemental analysis calculated for $\mathrm{C}_{20} \mathrm{H}_{15} \mathrm{~N}_{3} \mathrm{OS}$ (345.43 g/mol): C 69.54\%, H 4.38\%, N 12.16\%, S 9.28\% and found: C $69.48 \%, \mathrm{H} 4.46 \%$, $\mathrm{N} 12.26 \%$, S $9.19 \%$.

\subsection{Anticancer Evaluation}

\subsubsection{Reagents}

Cisplatin (CisPt), doxorubicin (DOX), and dimethyl sulfoxide (DMSO) were purchased from Sigma-Aldrich (St. Louis, MO, USA). The stock solutions were prepared by dissolving the compounds in a minimum amount of DMSO and kept at $-20{ }^{\circ} \mathrm{C}$. The working solutions were prepared before each experiment from the stocks and the culture medium. Annexin V-FITC/PI Apoptosis Detection Kit for flow cytometry was purchased from BioVision Inc., Milpitas, CA, USA. Cycletest Plus DNA Reagent Kit was provided by BD Biosciences (Becton Dickinson, USA).

\subsubsection{Cell Culture and Treatments}

Human cancer cell lines HT-29 (colon adenocarcinoma) and MDA-MB-231 (breast adenocarcinoma) were purchased from American Type Culture Collection (ATCC). Adherent cells were routinely maintained in culture in Dulbecco's modified Eagle medium/nutrient mixture F-12 (DMEM:F12) medium added by $2 \mathrm{mM}$ of L-glutamine, $10 \%$ fetal bovine serum, 100 units $/ \mathrm{mL}$ penicillin, $100 \mu \mathrm{g} / \mathrm{mL}$ streptomycin (Sigma-Aldrich, St. Louis, Mo, USA) and incubated at $37^{\circ} \mathrm{C}$ in $5 \% \mathrm{CO}_{2}$ humidified atmosphere. After $24 \mathrm{~h}$, adherent cells were treated with different concentrations of the compounds for different periods of time. Cell treatments of compounds, CisPt and DOX were carried out using concentrations of 200, $100,50,25,12.5$ and $6.25 \mu \mathrm{M}$ of the drug. Then cells were detached with a nonenzymatic solution of phosphate-buffered saline (PBS) / 1 mM EDTA, washed twice in PBS.

\subsubsection{Cytotoxicity Assay}

All assays were performed in triplicate in 96-well microtiter plates with flat bottom (Falcon), using CellTiter 96 Aqueous One Solution Cell Proliferation Assay (Promega), an MTS (3-(4,5-dimethylthiazol-2-yl)-5-(3-carboxymethoxyphenyl)-2-(4-sulfophenyl)-2Htetrazolium)-based colorimetric assay. Briefly, $1 \times 10^{4}$ cells/wells were cultured in $100 \mu \mathrm{L}$ for $24 \mathrm{~h}$, culture supernatants were discarded, and then cells were treated for $24 \mathrm{~h}$ and $48 \mathrm{~h}$ with increasing concentrations of drugs. After the end of the incubation time, $20 \mu \mathrm{L}$ reagent containing a) MTS, and b) phenazine ethosulfate (PES) were added in each well. PES has a high chemical stability that allows it to bind to MTS and form a stable solution. After adding the coloring solution, plates were incubated for $4 \mathrm{~h}$ at $37^{\circ} \mathrm{C}$, with mild agitation every $15 \mathrm{~min}$. The method relies on the ability of metabolically active cells to reduce MTS, a yellow tetrazolium salt to the colored formazan that is soluble in the culture medium. The reduction in the tetrazolium compound to formazan was spectrophotometrically measured at $\lambda=492 \mathrm{~nm}$, using a Dynex plate reader (DYNEX Technologies-MRS). The percentage of viability compared to untreated cells (considered $100 \%$ viable) was calculated based on the absorbance (Abs) values as follows:

$$
\begin{aligned}
\text { Cell viability }(\%)= & (\text { Abs treated cells }- \text { Abs culture medium }) /(\text { Abs untreated } \\
& \text { cells }- \text { Abs culture medium }) \times 100,
\end{aligned}
$$


Cell viability data were expressed as the mean values \pm standard deviations (SD) of the experiments. Data were obtained in triplicates $(n=3)$, averaged and expressed as mean \pm SD.

\subsubsection{Apoptosis Analysis}

The apoptosis assay was carried out using the Annexin V-FITC Kit and the manufacturer's protocol from BD Biosciences. The $5 \times 10^{5}$ cells $/ \mathrm{mL}$ treated and untreated were suspended in cold binding buffer and stained simultaneously with $5 \mu$ L FITC-Annexin V (green fluorescence) and $5 \mu \mathrm{L}$ PI in a dark at room temperature for $15 \mathrm{~min}$. The percentages of apoptotic cells were determined by double staining with Annexin V-FITC/ PI. In each tube was added $400 \mu \mathrm{L}$ of Annexin V binding buffer and the 5000 cells/sample were collected using FACSCantoII flow cytometer (Becton Dickinson-BD) and the analysis was performed using DIVA 6.2 software in order to identify early apoptosis (Annexin+/PI-), late apoptosis (Annexin+/PI+) and necrosis (Annexin-/PI+) [48].

\subsubsection{Cell Cycle Analysis}

The assay was carried out using Cycletest Plus DNA Reagent Kit and the manufacturer's protocol from BD Biosciences. Previously fixed cells $\left(5 \times 10^{5}\right)$ were washed twice in PBS and cell pellets were resuspended in PBS. The probes were kept in the dark and at $4{ }^{\circ} \mathrm{C}$ until data acquisition by flow cytometry using a FACSCantoII flow cytometer (Becton Dickinson-BD). The analysis was performed using ModFIT software in order to estimate the DNA index (DI) and progression through cell cycle phases [49].

\subsection{Daphnia Magna Toxicity Assay}

D. magna Straus was maintained parthenogenetically at 'Carol Davila' University (Department of Pharmaceutical Botany and Cell Biology). The culture was maintained at $25^{\circ} \mathrm{C}$, a photoperiod of $16 \mathrm{~h} / 8 \mathrm{~h}$ light/dark cycle. Prior to the determination, young daphnids were selected according to their size and maintained for $24 \mathrm{~h}$ in artificial medium. The bioassay was performed on 10 daphnids / replicates in tissue culture plates with 12 wells (Greiner Bio-One) according to the protocol described in our previous studies [50,51]. For each compound, six concentrations were tested, ranging from 5 to $128 \mu \mathrm{M}$. The hydrazides 2a $(20-411 \mu \mathrm{M})$ and $2 \mathbf{b}(20-394 \mu \mathrm{M})$ were used as positive controls, and a $1 \%$ DMSO solution as a negative control. The concentrations were selected based on the solubility and a pre-screening assay. The final volume/well was $4 \mathrm{~mL}$, and the lethality was recorded at 24 and $48 \mathrm{~h}$ of exposure. All determinations were performed in duplicate. The $95 \%$ confidence intervals $(95 \% \mathrm{CI})$ for LC50 values were also calculated using the least square fit method. All calculations were performed using GraphPad Prism v 5.1 software.

\subsection{Prediction of the Molecular Mechanism of Action and Toxicity}

\subsubsection{PASS Prediction}

A virtual screening was performed using the computer program PASS (prediction of activity spectra for substances), a software product designed to evaluate the general biological potential drug-like molecules. The compounds were inputted in PASS as mol files and the results were analyzed if the Pa values were above the corresponding $\mathrm{Pi}$ values. The resulted biological targets were manually selected based on their anticancer treatment potential.

\subsubsection{Structural Similarity Analysis}

A similarity search was performed on the ChEMBL database for each compound 3a-e using a 50\% threshold. The resulting structures were extracted together with their assayed activities on human targets [52]. The entries were filtered using DataWarrior v5.2.1 software [53] to remove compounds with inexact potency values and to merge duplicate structures into single entries with calculated average pIC50 or pEC50 values expressed as $\mathrm{mol} / \mathrm{L}(\mathrm{M})$. 


\subsubsection{Prediction of the Compounds' Toxicity}

The freely available program GUSAR was used to predict the LD50 values of the new compounds after oral and intravenous administration on rats [54].

\section{Patents}

Patent application a202000446: Camelia Elena Stecoza, George Mihai Nitulescu, Mirela Antonela Mihaila, Marinela Bostan, Constantin Draghici, Miron Teodor Caproiu, 2-Aryl(heteroaryl)-5-[2-(phenylthiomethyl)phenyl]-1,3,4-oxadiazole derivatives, a pharmaceutical composition containing them and their use as antitumor agent, published in RO-BOPI, 11/2020 from 27 November 2020.

Author Contributions: Conceptualization, C.E.S.; methodology and investigation, C.E.S., G.M.N., C.D., M.T.C., O.T.O., M.B., M.M.; writing—original draft preparation, C.E.S., G.M.N., C.D., M.T.C., O.T.O., M.B., M.M.; writing—review and editing, C.E.S., G.M.N., M.M. All authors have read and agreed to the published version of the manuscript.

Funding: This research received no external funding. The APC was funded by the authors.

Institutional Review Board Statement: Not applicable.

Informed Consent Statement: Not applicable.

Data Availability Statement: The datasets used and/or analysed during the current study are available from the corresponding author on reasonable request.

Conflicts of Interest: The authors declare no conflict of interest.

\section{References}

1. Sung, H.; Ferlay, J.; Siegel, R.L.; Laversanne, M.; Soerjomataram, I.; Jemal, A.; Bray, F. Global cancer statistics 2020: GLOBOCAN estimates of incidence and mortality worldwide for 36 cancers in 185 countries. CA. Cancer J. Clin. 2021, 68, 394-424.

2. Wang, X.; Zhang, H.; Chen, X. Drug resistance and combating drug resistance in cancer. Cancer Drug Resist. 2019, 2, 141-160. [CrossRef]

3. Schirrmacher, V. From chemotherapy to biological therapy: A review of novel concepts to reduce the side effects of systemic cancer treatment (Review). Int. J. Oncol. 2019, 54, 407-419.

4. Ion, G.N.D.; Olaru, O.T.; Nitulescu, G.; Olaru, I.I.; Tsatsakis, A.; Burykina, T.I.; Spandidos, D.A.; Nitulescu, G.M. Improving the odds of success in antitumoral drug development using scoring approaches towards heterocyclic scaffolds. Oncol. Rep. 2020, 44, 589-598. [CrossRef]

5. Lang, D.K.; Kaur, R.; Arora, R.; Saini, B.; Arora, S. Nitrogen-Containing Heterocycles as Anticancer Agents: An Overview. Anti-Cancer Agents Med. Chem. 2020, 20, 2150-2168. [CrossRef]

6. Boström, J.; Hogner, A.; Llinàs, A.; Wellner, E.; Plowright, A.T. Oxadiazoles in medicinal chemistry. J. Med. Chem. 2012, 55, 1817-1830. [CrossRef]

7. Benassi, A.; Doria, F.; Pirota, V. Groundbreaking anticancer activity of highly diversified oxadiazole scaffolds. Int. J. Mol. Sci. 2020, 21, 8692. [CrossRef]

8. Glomb, T.; Szymankiewicz, K.; Świątek, P. Anti-cancer activity of derivatives of 1,3,4-oxadiazole. Molecules $2018,23,3361$. [CrossRef]

9. Akhtar, J.; Khan, A.A.; Ali, Z.; Haider, R.; Shahar Yar, M. Structure-activity relationship (SAR) study and design strategies of nitrogen-containing heterocyclic moieties for their anticancer activities. Eur. J. Med. Chem. 2017, 125, 143-189. [CrossRef] [PubMed]

10. Sankhe, N.M.; Durgashivaprasad, E.; Gopalan Kutty, N.; Venkata Rao, J.; Narayanan, K.; Kumar, N.; Jain, P.; Udupa, N.; Vasanth Raj, P. Novel 2,5-disubstituted-1,3,4-oxadiazole derivatives induce apoptosis in HepG2 cells through p53 mediated intrinsic pathway. Arab. J. Chem. 2019, 12, 2548-2555. [CrossRef]

11. Hamdy, R.; Elseginy, S.A.; Ziedan, N.I.; El-Sadek, M.; Lashin, E.; Jones, A.T.; Westwell, A.D. Design, synthesis and evaluation of new bioactive oxadiazole derivatives as anticancer agents targeting bcl-2. Int. J. Mol. Sci. 2020, 21, 8980. [CrossRef]

12. Sun, J.; Li, M.H.; Qian, S.S.; Guo, F.J.; Dang, X.F.; Wang, X.M.; Xue, Y.R.; Zhu, H.L. Synthesis and antitumor activity of 1,3,4oxadiazole possessing 1,4-benzodioxan moiety as a novel class of potent methionine aminopeptidase type II inhibitors. Bioorg. Med. Chem. Lett. 2013, 23, 2876-2879. [CrossRef]

13. Zhang, X.M.; Qiu, M.; Sun, J.; Zhang, Y.B.; Yang, Y.S.; Wang, X.L.; Tang, J.F.; Zhu, H.L. Synthesis, biological evaluation, and molecular docking studies of 1,3,4-oxadiazole derivatives possessing 1,4-benzodioxan moiety as potential anticancer agents. Bioorg. Med. Chem. 2011, 19, 6518-6524. [CrossRef] 
14. Bajaj, S.; Roy, P.P.; Singh, J. 1,3,4-Oxadiazoles as Telomerase Inhibitor: Potential Anticancer Agents. Anti-Cancer Agents Med. Chem. 2017, 17, 1869-1883. [CrossRef] [PubMed]

15. Zhang, S.; Luo, Y.; He, L.Q.; Liu, Z.J.; Jiang, A.Q.; Yang, Y.H.; Zhu, H.L. Synthesis, biological evaluation, and molecular docking studies of novel 1,3,4-oxadiazole derivatives possessing benzotriazole moiety as FAK inhibitors with anticancer activity. Bioorg. Med. Chem. 2013, 21, 3723-3729. [CrossRef]

16. Du, Q.R.; Li, D.D.; Pi, Y.Z.; Li, J.R.; Sun, J.; Fang, F.; Zhong, W.Q.; Gong, B.-H.; Zhu, H.L. Novel 1,3,4-oxadiazole thioether derivatives targeting thymidylate synthase as dual anticancer/antimicrobial agents. Bioorg. Med. Chem. 2013, 21, $2286-2297$. [CrossRef] [PubMed]

17. Bajaj, S.; Asati, V.; Singh, J.; Roy, P.P. 1,3,4-Oxadiazoles: An emerging scaffold to target growth factors, enzymes and kinases as anticancer agents. Eur. J. Med. Chem. 2015, 97, 124-141. [CrossRef]

18. Khan, K.M.; Rani, M.; Ambreen, N.; Ali, M.; Hussain, S.; Perveen, S.; Choudhary, M.I. 2,5-Disubstituted-1,3,4-oxadiazoles: Thymidine phosphorylase inhibitors. Med. Chem. Res. 2013, 22, 6022-6028. [CrossRef]

19. Alam, M.M.; Almalki, A.S.; Neamatallah, T.; Ali, N.M.; Malebari, A.M.; Nazreen, S. Synthesis of New 1, 3, 4-OxadiazoleIncorporated 1, 2, 3-Triazole Moieties as Potential Anticancer Agents Targeting Thymidylate Synthase and Their Docking Studies. Pharmaceuticals 2020, 13, 390. [CrossRef] [PubMed]

20. Liu, K.; Lu, X.; Zhang, H.J.; Sun, J.; Zhu, H.L. Synthesis, molecular modeling and biological evaluation of 2-(benzylthio)-5aryloxadiazole derivatives as anti-tumor agents. Eur. J. Med. Chem. 2012, 47, 473-478. [CrossRef]

21. Akhtar, M.J.; Siddiqui, A.A.; Khan, A.A.; Ali, Z.; Dewangan, R.P.; Pasha, S.; Yar, M.S. Design, synthesis, docking and QSAR study of substituted benzimidazole linked oxadiazole as cytotoxic agents, EGFR and erbB2 receptor inhibitors. Eur. J. Med. Chem. 2017, 126, 853-869. [CrossRef] [PubMed]

22. Ruel, R.; Thibeault, C.; L'Heureux, A.; Martel, A.; Cai, Z.W.; Wei, D.; Qian, L.; Barrish, J.C.; Mathur, A.; D’Arienzo, C.; et al. Discovery and preclinical studies of 5-isopropyl-6-(5-methyl-1,3,4-oxadiazol-2-yl)-N-(2-methyl-1H-pyrrolo[2,3-b]pyridin-5yl)pyrrolo[2,1-f][1,2,4]triazin-4-amine (BMS-645737), an in vivo active potent VEGFR-2 inhibitor. Bioorg. Med. Chem. Lett. 2008, 18, 2985-2989. [CrossRef] [PubMed]

23. Kamal, A.; Srikanth, P.S.; Vishnuvardhan, M.V.P.S.; Kumar, G.B.; Suresh Babu, K.; Hussaini, S.M.A.; Kapure, J.S.; Alarifi, A. Combretastatin linked 1,3,4-oxadiazole conjugates as a Potent Tubulin Polymerization inhibitors. Bioorg. Chem. 2016, 65, 126-136. [CrossRef] [PubMed]

24. Rajak, H.; Agarawal, A.; Parmar, P.; Thakur, B.S.; Veerasamy, R.; Sharma, P.C.; Kharya, M.D. 2,5-Disubstituted-1,3,4oxadiazoles/thiadiazole as surface recognition moiety: Design and synthesis of novel hydroxamic acid based histone deacetylase inhibitors. Bioorg. Med. Chem. Lett. 2011, 21, 5735-5738. [CrossRef]

25. Valente, S.; Trisciuoglio, D.; De Luca, T.; Nebbioso, A.; Labella, D.; Lenoci, A.; Bigogno, C.; Dondio, G.; Miceli, M.; Brosch, G.; et al. 1,3,4-Oxadiazole-containing histone deacetylase inhibitors: Anticancer activities in cancer cells. J. Med. Chem. 2014, 57, 6259-6265. [CrossRef] [PubMed]

26. Terenzi, A.; Fanelli, M.; Ambrosi, G.; Amatori, S.; Fusi, V.; Giorgi, L.; Turco Liveri, V.; Barone, G. DNA binding and antiproliferative activity toward human carcinoma cells of copper(ii) and zinc(ii) complexes of a 2,5-diphenyl[1,3,4]oxadiazole derivative. Dalt. Trans. 2012, 41, 4389-4395. [CrossRef]

27. Stecoza, C.; Majekova, M.; Majek, P.; Caproiu, M.; Marutescu, L. Novel Dibenzothiepins with Antibiofilm Activity Demonstrated by Microbiological Assays and Molecular Modeling. Curr. Org. Chem. 2013, 17, 113-124. [CrossRef]

28. Stecoza, C.E.; Ilie, C.; Caproiu, M.T.; Draghici, C. New 2-metyl-O-acyloximino-dibenzo [b,e] thiepins Synthesis and structural characterization. Rev. Chim. 2011, 62, 610-613.

29. Patra, A.; Ghorai, S.K.; De, S.R.; Mal, D. Regiospecific Synthesis of Benzo[b]fluorenones via Ring Contraction by Benzil-Benzilic Acid Rearrangement of Benz[a]anthracene-5,6-diones. Synthesis 2006, 2006, 2556-2562. [CrossRef]

30. Kumar, H.; Javed, S.A.; Khan, S.A.; Amir, M. 1,3,4-Oxadiazole/thiadiazole and 1,2,4-triazole derivatives of biphenyl-4-yloxy acetic acid: Synthesis and preliminary evaluation of biological properties. Eur. J. Med. Chem. 2008, 43, 2688-2698. [CrossRef]

31. Gamal El-Din, M.M.; El-Gamal, M.I.; Abdel-Maksoud, M.S.; Yoo, K.H.; Oh, C.H. Synthesis and in vitro antiproliferative activity of new 1,3,4-oxadiazole derivatives possessing sulfonamide moiety. Eur. J. Med. Chem. 2015, 90, 45-52. [CrossRef]

32. Hustedt, N.; Durocher, D. The control of DNA repair by the cell cycle. Nat. Cell Biol. 2017, 19, 1-9. [CrossRef]

33. Lezaja, A.; Altmeyer, M. Inherited DNA lesions determine G1 duration in the next cell cycle. Cell Cycle 2018, 17, 24-32. [CrossRef] [PubMed]

34. Bostan, M.; Petrică-Matei, G.G.; Ion, G.; Radu, N.; Mihăilă, M.; Hainăroşie, R.; Braşoveanu, L.I.; Roman, V.; Constantin, C.; Neagu, M.T. Cisplatin effect on head and neck squamous cell carcinoma cells is modulated by ERK1/2 protein kinases. Exp. Ther. Med. 2019, 18, 5041-5051. [CrossRef]

35. Mihaila, M.; Bostan, M.; Hotnog, D.; Ferdes, M.; Brasoveanu, L.I. Real-time analysis of quercetin, resveratrol and/or doxorubicin effects in mcf-7 cells. Rom. Biotechnol. Lett. 2013, 18, 8106-8114.

36. Maciuca, A.-M.; Munteanu, A.-C.; Mihaila, M.; Badea, M.; Olar, R.; Nitulescu, G.M.; Munteanu, C.V.A.; Bostan, M.; Uivarosi, V. Rare-Earth Metal Complexes of the Antibacterial Drug Oxolinic Acid: Synthesis, Characterization, DNA/Protein Binding and Cytotoxicity Studies. Molecules 2020, 25, 5418. [CrossRef]

37. Bostan, M.; Petrică-Matei, G.G.; Radu, N.; Hainarosie, R.; Stefanescu, C.D.; Diaconu, C.C.; Roman, V. The Effect of Resveratrol or Curcumin on Head and Neck Cancer Cells Sensitivity to the Cytotoxic Effects of Cisplatin. Nutrients 2020, 12, 2596. [CrossRef] 
38. Filimonov, D.A.; Lagunin, A.A.; Gloriozova, T.A.; Rudik, A.V.; Druzhilovskii, D.S.; Pogodin, P.V.; Poroikov, V.V. Prediction of the biological activity spectra of organic compounds using the pass online web resource. Chem. Heterocycl. Compd. $2014,50,444-457$. [CrossRef]

39. Choi, S.; Jung, H.J.; Kim, M.W.; Kang, J.H.; Shin, D.; Jang, Y.S.; Yoon, Y.S.; Oh, S.H. A novel STAT3 inhibitor, STX-0119, attenuates liver fibrosis by inactivating hepatic stellate cells in mice. Biochem. Biophys. Res. Commun. 2019, 513, 49-55. [CrossRef]

40. Malojirao, V.H.; Girimanchanaika, S.S.; Shanmugam, M.K.; Sherapura, A.; Dukanya; Metri, P.K.; Vigneshwaran, V.; Chinnathambi, A.; Alharbi, S.A.; Rangappa, S.; et al. Novel 1,3,4-oxadiazole targets STAT3 signaling to induce antitumor effect in lung cancer. Biomedicines 2020, 8, 368. [CrossRef] [PubMed]

41. Khanam, R.; Hejazi, I.I.; Shahabuddin, S.; Bhat, A.R.; Athar, F. Pharmacokinetic evaluation, molecular docking and in vitro biological evaluation of 1, 3, 4-oxadiazole derivatives as potent antioxidants and STAT3 inhibitors. J. Pharm. Anal. 2019, 9, 133-141. [CrossRef]

42. Verhoeven, Y.; Tilborghs, S.; Jacobs, J.; De Waele, J.; Quatannens, D.; Deben, C.; Prenen, H.; Pauwels, P.; Trinh, X.B.; Wouters, A.; et al. The potential and controversy of targeting STAT family members in cancer. Semin. Cancer Biol. 2020, 60, 41-56. [CrossRef] [PubMed]

43. Matsuno, K.; Masuda, Y.; Uehara, Y.; Sato, H.; Muroya, A.; Takahashi, O.; Yokotagawa, T.; Furuya, T.; Okawara, T.; Otsuka, M.; et al. Identification of a New Series of STAT3 Inhibitors by Virtual Screening. ACS Med. Chem. Lett. 2010, 1, 371-375. [CrossRef] [PubMed]

44. Chen, H.; Yang, Z.; Ding, C.; Chu, L.; Zhang, Y.; Terry, K.; Liu, H.; Shen, Q.; Zhou, J. Fragment-based drug design and identification of HJC0123, a novel orally bioavailable STAT3 inhibitor for cancer therapy. Eur. J. Med. Chem. 2013, 62, 498-507. [CrossRef]

45. Corvinus, F.M.; Orth, C.; Moriggl, R.; Tsareva, S.A.; Wagner, S.; Pfitzner, E.B.; Baus, D.; Kaufmann, R.; Huber, L.A.; Zatloukal, K.; et al. Persistent STAT3 activation in colon cancer is associated with enhanced cell proliferation and tumor growth. Neoplasia 2005, 7, 545-555. [CrossRef] [PubMed]

46. Yan, L.X.; Wu, Q.N.; Zhang, Y.; Li, Y.Y.; Liao, D.Z.; Hou, J.H.; Fu, J.; Zeng, M.S.; Yun, J.P.; Wu, Q.L.; et al. Knockdown of miR-21 in human breast cancer cell lines inhibits proliferation, in vitro migration and in vivo tumor growth. Breast Cancer Res. 2011, 13, 1-14. [CrossRef] [PubMed]

47. Li, C.; Zhao, L.; Chen, Y.; He, T.; Chen, X.; Mao, J.; Li, C.; Lyu, J.; Meng, Q.H. MicroRNA-21 promotes proliferation, migration, and invasion of colorectal cancer, and tumor growth associated with down-regulation of sec23a expression. BMC Cancer 2016, 16, 605. [CrossRef]

48. Botezatu, A.; Iancu, I.V.; Plesa, A.; Manda, D.; Popa, O.; Bostan, M.; Mihaila, M.; Albulescu, A.; Fudulu, A.; Vladoiu, S.V.; et al. Methylation of tumour suppressor genes associated with thyroid cancer. Cancer Biomark. 2019, 25, 53-65. [CrossRef]

49. Hotnog, D.; Mihaila, M.; Botezatu, A.; Matei, G.G.; Hotnog, C.; Anton, G.; Bostan, M.; Brasoveanu, L.I. Genistein potentiates the apoptotic effect of 5-fluorouracyl in colon cancer cell lines. Rom. Biotechnol. Lett. 2013, 18, 7151-7160.

50. Nitulescu, G.; Mihai, D.P.; Nicorescu, I.M.; Olaru, O.T.; Ungurianu, A.; Zanfirescu, A.; Nitulescu, G.M.; Margina, D. Discovery of natural naphthoquinones as sortase A inhibitors and potential anti-infective solutions against Staphylococcus aureus. Drug Dev. Res. 2019, 80, 1136-1145. [CrossRef] [PubMed]

51. Seremet, O.C.; Olaru, O.T.; Gutu, C.M.; Nitulescu, G.M.; Ilie, M.; Negres, S.; Zbarcea, C.E.; Purdel, C.N.; Spandidos, D.A.; Tsatsakis, A.M.; et al. Toxicity of plant extracts containing pyrrolizidine alkaloids using alternative invertebrate models. Mol. Med. Rep. 2018, 17, 7757-7763. [CrossRef] [PubMed]

52. Mendez, D.; Gaulton, A.; Bento, A.P.; Chambers, J.; De Veij, M.; Félix, E.; Magariños, M.P.; Mosquera, J.F.; Mutowo, P.; Nowotka, M.; et al. ChEMBL: Towards direct deposition of bioassay data. Nucleic Acids Res. 2019, 47, D930-D940. [CrossRef]

53. Sander, T.; Freyss, J.; von Korff, M.; Rufener, C. DataWarrior: An Open-Source Program for Chemistry Aware Data Visualization and Analysis. J. Chem. Inf. Model. 2015, 55, 460-473. [CrossRef]

54. Zakharov, A.V.; Peach, M.L.; Sitzmann, M.; Nicklaus, M.C. A new approach to radial basis function approximation and its application to QSAR. J. Chem. Inf. Model. 2014, 54, 713-719. [CrossRef] [PubMed] 